\title{
A Single Amino Acid Substitution in the Antimicrobial Defense Protein Cecropin B Is Associated with Diminished Degradation by Leaf Intercellular Fluid
}

\author{
Lowell D. Owens and Thomas M. Heutte \\ U.S. Department of Agriculture, Agricultural Research Service, Plant Molecular Biology Laboratory, \\ Beltsville, MD 20705, U.S.A. \\ Received 2 December 1996. Accepted 4 February 1997.
}

\begin{abstract}
Degradation is one of several factors that may affect the level of accumulation of transgene products in plants. In plants engineered to secrete antimicrobial proteins to the intercellular compartment of leaves, the degradative activity of proteases residing in leaf intercellular fluid (IF) could be critical to achieving the expected transgene function. We synthesized a structural analogue (MB39) of the antibacterial protein cecropin $B$ and compared the susceptibility of both proteins to degradation in vitro by IF extracted from leaves of various crops. The half-life of the two proteins in the various IF extracts ranged from $3 \mathrm{~min}$ to $25.5 \mathrm{~h}$, with the analogue MB39 displaying the longer half-life in IF from nine of $\mathbf{1 0}$ species. Overall, the half-life of MB39 averaged 2.9 times greater than that of cecropin B. Analysis of the peptides produced by endopeptidase activity in potato IF indicated that the 5.7-fold lower degradation rate of MB39 was associated with the substitution of valine for methionine at residue 11 of cecropin $B$. These findings point to the possibility of tailoring antimicrobial protein genes to reduce the rate of protein degradation in a particular target crop.
\end{abstract}

The introduction into plants of genes encoding small antimicrobial proteins has proved to be an effective way of enhancing resistance to bacterial and fungal pathogens (Carmona et al. 1993; Jaynes et al. 1993; Norelli et al. 1994; Terras et al. 1995). Despite these reported successes, however, the level of enhanced resistance in other instances has often been modest (Hassan et al. 1993; Huang et al., in press) or nil (Hightower et al. 1994; Allefs et al. 1995; Florack et al. 1995). The accumulation of transgene proteins in plants may be influenced by many factors (Owens 1995), including the rate at which synthesized proteins are degraded. Consequently, engineering a protein to resist degradation by proteases could, conceivably, enhance the accumulation of that protein in the transgenic plant.

Corresponding author: L. D. Owens; E-mail: lowens@asrr.arsusda.gov

This article is in the public domain and not copyrightable. It may be freely reprinted with customary crediting of the source. The American Phytopathological Society, 1997.
MB39 is a structural analogue of the antibacterial peptide cecropin B (see Boman and Hultmark 1987 for review). It differs from the latter by (i) the substitution of Val for $\mathrm{Met}^{11}$, to eliminate a translational start codon, (ii) the addition of a tripeptide to the $\mathrm{N}$ terminus, to create a signal-peptide cleavage site, and (iii) the substitution of a Gly residue for the amide group at the $\mathrm{C}$ terminus, Gly being the post-translational source of the amide group in cecropin B (Fig. 1). The two peptides are about equally active against a number of plant pathogens (Table 1).

Recently, we introduced into several crops a synthetic gene encoding MB39. Since the gene was designed to facilitate the secretion of the mature MB39 polypeptide into the intercellular spaces, we examined the rates of degradation of cecropin $B$ and MB39 by leaf intercellular fluids (IFs) in vitro, and found substantial differences.

The degradative activity of IFs from the 10 crops varied widely with species and, to some extent, with the time of season (Table 2). The half-lives of the two proteins in these IF extracts ranged from $3 \mathrm{~min}$ to $25.5 \mathrm{~h}$ (Table 2), and varying patterns of degradation were observed (Fig. 2).

Susceptibility to proteolysis was greatly influenced by the amino acid sequence of the protein. MB39 was degraded less rapidly than cecropin B by leaf IFs extracted from nine of the 10 crops tested (Table 2).

The cause for differential degradation was investigated with potato IF, which degraded cecropin B some 5.7 times more rapidly than MB39 (Table 2). Potato IF stoichiometrically converted cecropin B to a $2.4-\mathrm{kDa}$ C-terminal fragment (Figs. 2 and 3) and a smaller N-terminal fragment not detected by

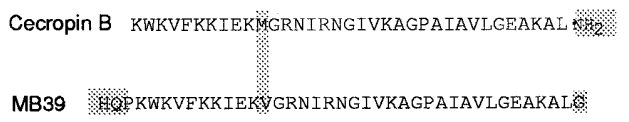

Fig. 1. Structures of cecropin B (purchased from Bachem California, Torrance, CA) and the synthetic analogue MB39, which was synthesized with a model 431A peptide synthesizer (ABI, Foster City, CA) and purified by reverse-phase chromatography on a Delta pak $\mathrm{C}_{18}$ column, $19 \times$ $300 \mathrm{~mm}$ (Nihon Millipore, Tokyo) with a linear gradient of $0.1 \%$ trifluoracetic acid (TFA) to $50 \%$ acetonitrile/0.1\% TFA in $45 \mathrm{~min}$ at 4 $\mathrm{ml} / \mathrm{min}$. Differences between the molecules are shaded. 
polyacrylamide gel electrophoresis (PAGE). N-terminal sequencing of the 2.4-kDa fragment indicated that cleavage had occurred at the $\mathrm{Met}^{11}$ residue (Fig. 4). This was confirmed by directly analyzing reaction mixtures of cecropin $\mathrm{B}$ and potato IF (without purification) by mass spectrometry (calculated $\mathrm{M}$ $+\mathrm{H}=2,387 \mathrm{Da}$; observed $=2,387.8 \mathrm{Da}$ ), using a matrixassisted laser absorption/ionization time-of-flight (MALDITOF) instrument (Kompact MALDI-II, Shimadzu Scientific Instruments, Columbia, MD).

In contrast, MB39, which has Val substituted for the Met ${ }^{11}$ of cecropin B, was cleaved at the $\mathrm{Lys}^{36}$ residue (equivalent to $\mathrm{Lys}^{33}$ of cecropin B) to yield the major 4.0-kDa peptide, as determined by PAGE (Fig. 2). No fragments indicative of cleavage at $\mathrm{Val}^{14}$ were observed with PAGE or detected by peptide sequencing (Fig. 4) or mass spectrometry. However, lesser amounts of fragments of approximately 2.7 and $2.1 \mathrm{kDa}$ were observed, apparently from additional endopeptidase cleavages at $\mathrm{Glu}^{12}$ and $\mathrm{Gln}^{17}$ (Fig. 4).

Everett (1994) has reported that N- and C-terminal modifications of magainin-like polypeptides can affect their susceptibility to proteolysis by leaf IF, presumably by lowering the peptide's sensitivity to exopeptidases. In our detailed study of

Table 1. In vitro antimicrobial activities of cecropin B and the synthetic analogue MB39 against selected plant pathogens ${ }^{\mathrm{a}}$

\begin{tabular}{|c|c|c|c|}
\hline \multirow[b]{2}{*}{ Plant pathogen (host) } & \multirow[b]{2}{*}{ Strain } & \multicolumn{2}{|c|}{$\begin{array}{l}\text { Lethal concentra- } \\
\text { tion }(\mu \mathrm{M})^{\mathrm{b}}\end{array}$} \\
\hline & & Cecropin B & MB39 \\
\hline \multicolumn{4}{|l|}{ Bacteria } \\
\hline $\begin{array}{l}\text { Erwinia carotovora subsp. beta- } \\
\quad \text { vasculorum (sugarbeet) }\end{array}$ & ECBV-A & 1.6 & 2.7 \\
\hline $\begin{array}{l}\text { Clavibacter michiganense subsp. } \\
\text { michiganense (tomato) }\end{array}$ & $1282-4$ & 3.9 & 3.5 \\
\hline $\begin{array}{l}\text { Pseudomonas } \\
\text { cinea (soybe }\end{array}$ & $\operatorname{Pg} 5$ & 0.6 & 1.5 \\
\hline abaci (tobacco) & & 2.1 & 1.9 \\
\hline & $683-2$ & & \\
\hline $\begin{array}{l}\text { campestrls pv. } \\
\text { h) }\end{array}$ & XP1 & 1.0 & 1.3 \\
\hline $\begin{array}{l}\text { X. campestris pv. vesicatoria } \\
\text { (tomato) }\end{array}$ & 0985-16 & 2.8 & 1.0 \\
\hline \multicolumn{4}{|l|}{ ungi } \\
\hline Phytophthera infesta & US-8 & 0.7 & 0.9 \\
\hline Rhizoctonia solani & $\mathrm{AG} 2$ & 0.9 & 1.9 \\
\hline \multicolumn{4}{|c|}{$\begin{array}{l}\text { Two microliters of test protein }(1 \mu \mathrm{g} / \mu \mathrm{l}) \text { dissolved in water was added } \\
\text { to wells }(2 \mathrm{~mm} \text { diaeter) in thin-agarose (SeaPlaque, } 1 \%) \text { petri plates, } \\
\text { according to the method of Hultmark et al. (1983) as modified by Nor- } \\
\text { deen et al. (1992). Plates contained } 6 \mathrm{ml} \text { of agarose-solidified nutrient } \\
\text { broth yeast extract medium without } \mathrm{MgSO}_{4} \text { (Schaad 1988) seeded with } \\
\text { bacteria }\left(10^{6} \mathrm{CFU} / \mathrm{ml}\right) \text { or rye infusion glucose }(P \text {. infestans) or potato } \\
\text { dextrose }(R . \text { solani) media (Schaad } 1988) \text { inoculated in the center of } \\
\text { the plate with an agar plug ( }(7 \mathrm{~mm} \text { diameter) of fungal mycelia. Wells } \\
\text { in the fungal plates were positioned } 1 \mathrm{~cm} \text { from the periphery of the } \\
\text { mycelia after the mycelia had grown to a diameter of about } 2.5 \mathrm{~cm} \text {. } \\
\text { Bacterial plates were incubated at } 28^{\circ} \mathrm{C} \text { in the dark; } R \text {. solani plates at } \\
\text { room temperature in the laboratory; and } P \text {. infestans plates right-side } \\
\text { up, to minimize growth toward the lid, at } 20^{\circ} \mathrm{C} \text { under continuous, low- } \\
\text { intensity ( } 9 \mathrm{~W}) \text {, fluorescent light. } \\
\text { b Minimum lethal (bacteria) or minimum inhibitory (fungi) concentra- } \\
\text { tions were calculated from inhibition zone diameters according to the } \\
\text { mathematical model of Hultmark et al. (1983). Values are means of } \\
\text { two or more replicates. After scoring at } 2 \text { or } 3 \text { days, fungal mycelia } \\
\text { continued to grow at reduced rates into the inhibition zones, hence the } \\
\text { term "minimum inhibitory concentration" is used to describe the fun- } \\
\text { gal response rather than "minimum lethal concentration" descriptive of } \\
\text { the bacterial response. }\end{array}$} \\
\hline
\end{tabular}

cecropin B and MB39 degradation by potato IF, proteolysis appeared to proceed via an initial endopeptidase cleavage. It seems unlikely, therefore, that $\mathrm{N}$ - and $\mathrm{C}$-terminal modifications in MB39 could have significantly affected its sensitivity to this endopeptidase.

For other crop species, however, these changes at the $\mathrm{N}$ - and C-termini of MB39 may well have contributed to its generally enhanced half-life in leaf IF. The degradative patterns for IF from different crops were quite varied (Fig. 2), but neither the initial nor inactivating cleavages were determined. And, since the enhancements varied from nil to 7.3-fold (Table 2), the precise structural changes needed to substantially enhance stability may be somewhat specific for each crop.

The steady state level of a secreted protein represents the balance between secretion and degradation. Our observation that relatively small changes in amino acid sequence of a protein can greatly affect its rate of degradation by leaf IF suggests that tailoring antimicrobial genes for use in a particular crop may be feasible. This approach is especially attractive for small $(<5 \mathrm{kDa})$ antimicrobial proteins because analogues of the protein can be synthesized and tested against target pathogens, and DNA encoding the selected protein can be synthesized and incorporated into gene constructs.

Table 2. Degradation of cecropin analogues by leaf intercellular fluid $(\mathrm{IF})^{\mathrm{a}}$

\begin{tabular}{|c|c|c|c|}
\hline \multirow[b]{2}{*}{ Crop } & \multirow[b]{2}{*}{ Test protein } & \multicolumn{2}{|c|}{ Half-life } \\
\hline & & Time & Ratio $^{b}$ \\
\hline \multirow[t]{2}{*}{ Potato } & Cecropin B & $3 \mathrm{~min}$ & \\
\hline & MB39 & $17 \min$ & 5.7 \\
\hline \multirow{2}{*}{ Tomato } & Cecropin B & $7 \mathrm{~min}$ & \\
\hline & MB39 & $17 \mathrm{~min}$ & 2.4 \\
\hline \multicolumn{4}{|l|}{ Peach } \\
\hline \multirow[t]{2}{*}{ Spring leaves } & Cecropin B & $8 \mathrm{~min}$ & \\
\hline & MB39 & $58 \min$ & 7.3 \\
\hline \multirow{2}{*}{ Summer leaves } & Cecropin B & $12 \mathrm{~min}$ & \\
\hline & MB39 & $36 \min$ & 3.0 \\
\hline \multirow[t]{2}{*}{ Fall leaves } & Cecropin B & $20 \min ^{\mathrm{c}}$ & \\
\hline & MB39 & $78 \mathrm{~min}$ & 3.9 \\
\hline \multirow[t]{2}{*}{ Soybean } & Cecropin B & $1.0 \mathrm{~h}$ & \\
\hline & MB39 & $1.9 \mathrm{~h}$ & 1.9 \\
\hline \multirow[t]{2}{*}{ Sunflower } & Cecropin B & $1.7 \mathrm{~h}$ & \\
\hline & MB39 & $2.7 \mathrm{~h}$ & 1.6 \\
\hline \multirow{2}{*}{ Sugarcane } & Cecropin B & $2.5 \mathrm{~h}$ & \\
\hline & MB39 & $6.9 \mathrm{~h}$ & 2.8 \\
\hline \multicolumn{4}{|l|}{ Tobacco cvs. } \\
\hline \multirow[t]{2}{*}{ Bright Yellow } & Cecropin B & $2.9 \mathrm{~h}$ & \\
\hline & MB39 & $4.2 \mathrm{~h}$ & 1.4 \\
\hline \multirow[t]{2}{*}{ Bottom Special } & Cecropin B & $2.9 \mathrm{~h}$ & \\
\hline & MB39 & $2.9 \mathrm{~h}$ & 1.0 \\
\hline \multirow[t]{2}{*}{ Maize } & Cecropin B & $3.7 \mathrm{~h}$ & \\
\hline & MB39 & $10.3 \mathrm{~h}$ & 2.8 \\
\hline \multirow[t]{2}{*}{ Sugarbeet } & Cecropin B & $4.6 \mathrm{~h}$ & \\
\hline & MB39 & $5.8 \mathrm{~h}$ & 1.3 \\
\hline \multirow[t]{2}{*}{ Rice } & Cecropin B & $25.5 \mathrm{~h}$ & \\
\hline & MB39 & $9.0 \mathrm{~h}$ & 0.4 \\
\hline
\end{tabular}

${ }^{a}$ Cecropin B or MB39 $(2 \mu \mathrm{l} \mathrm{of} 1 \mu \mathrm{g} / \mu \mathrm{l})$ was incubated at room temperature with IF $(2 \mu \mathrm{l})$ for various lengths of time, subjected to polyacrylamide gel electrophoresis, stained with Coomassie brilliant blue, and scanned with a densitometer as described in Mills et al. (1994). Halflives were calculated from data plots of four incubation times and confirmed in a second experiment. IFs were obtained by centrifugation of leaves that had been vacuum infiltrated with sterile, deionized water (Mills et al. 1994) and used without further dilution.

${ }^{\mathrm{b}}$ MB39/cecropin B.

${ }^{c}$ Datum from Mills et al. (1994), presented for purpose of comparison. 


\section{ACKNOWLEDGMENTS}

We thank Brian Stall, Shimadzu Scientific Instruments, for performing the MALDI-TOF mass spectrometry. This research was funded in part by the Beet Sugar Development Foundation, project 800 .

\section{LITERATURE CITED}

Allefs, S. J. H. M., Florack, D. E. A., Hoogendoorn, C., and Stiekema, W. J. 1995. Erwinia soft rot resistance of potato cultivars transformed with a gene construct coding for antimicrobial peptide cecropin B is not altered. Am. Potato J. 72:437-445.

Boman, H. G., and Hultmark, D. 1987. Cell-free immunity in insects. Annu. Rev. Microbiol. 41:103-126.

Carmona, M. J., Molina, A., Fernandez, J. A., Lopez-Fando, J. J., and Garcia-Olmedo, F. 1993. Expression of the $\alpha$-thionin gene from barley in tobacco confers enhanced resistance to bacterial pathogens. Plant J. 3:457-462.
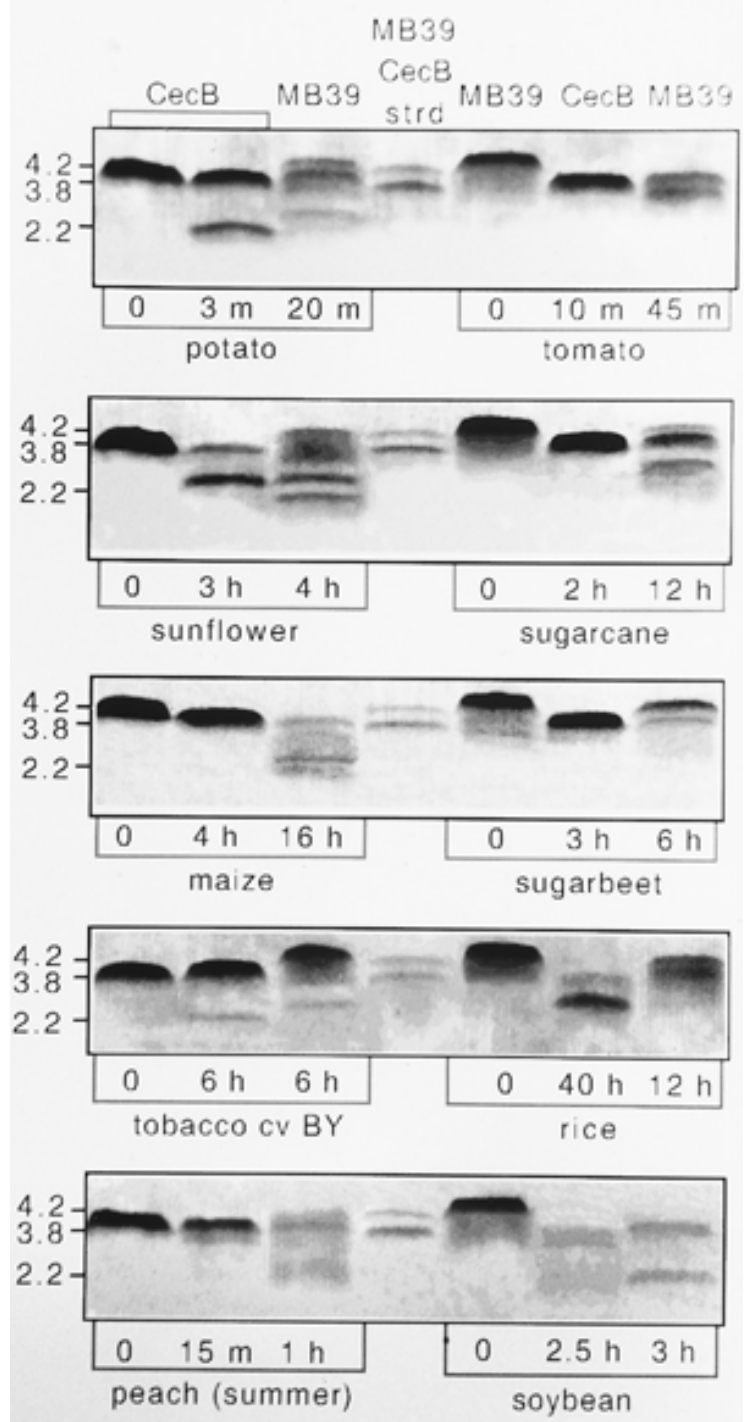

Fig. 2. Degradation of cecropin B and MB39 by leaf intercellular fluid (IF) from various crops. Cecropin B or MB39 $(2 \mu \mathrm{l}$ of $1 \mu \mathrm{g} / \mu \mathrm{l})$ was incubated with IF ( $2 \mu \mathrm{l})$ for the indicated lengths of time, subjected to polyacrylamide gel electrophoresis, stained with Coomassie brilliant blue, and scanned with a densitometer as described in Mills et al. (1994). For zero-time treatments, sodium dodecyl sulfate dye was added immediately and the tube placed in a $100^{\circ} \mathrm{C}$ bath.
Everett, N. P. 1994. Design of antifungal peptides for agricultural applications. Pages 278-291 in: Natural and Engineered Pest Management Agents. P. A. Hedin, J. J. Menn, and R. M. Hollingworth, eds. ACS Symp. Ser. 551, Am. Chem. Soc., Washington, DC.

Florack, D., Allefs, S., Bollen, R., Bosch, D., Visser, B., and Stiekema, W. 1995. Expression of giant silkmoth cecropin B genes in tobacco. Transgenic Res. 4:132-141.

Hassan, M., Sinden, S. S., Kobayashi, R. S., Nordeen, R. O., and Owens, L. D. 1993. Transformation of potato (Solanum tuberosum) with a gene for an anti-bacterial protein, cecropin. Acta Hortic. 336:127-131.

Hightower, R., Baden, C., Penzes, E., and Dunsmuir, P. 1994. The expression of cecropin peptide in transgenic tobacco does not confer resistance to Pseudomonas syringae pv tabaci. Plant Cell Rep. 13:295-299.

Huang, Y., Nordeen, R. O., Di, M., Owens, L. D., and McBeath, J. H. Expression of an engineered cecropin gene cassette confers disease resistance to Pseudomonas syringae pv. tabaci. Phytopathology. (In press.)

Hultmark, D., Engstrom, A., Andersson, K., Steiner, H., Bennich, H., and Boman, H. G. 1983. Insect immunity. Attacins, a family of antibacterial proteins from Hyalophora cecropia. EMBO J. 2:571-576.

Jaynes., J. M., Nagpala, P., Destefano-Beltran, L., Huang, J. H., Kim, J.-H., Denny, T., and Cetiner, S. 1993. Expression of a cecropin B lytic peptide

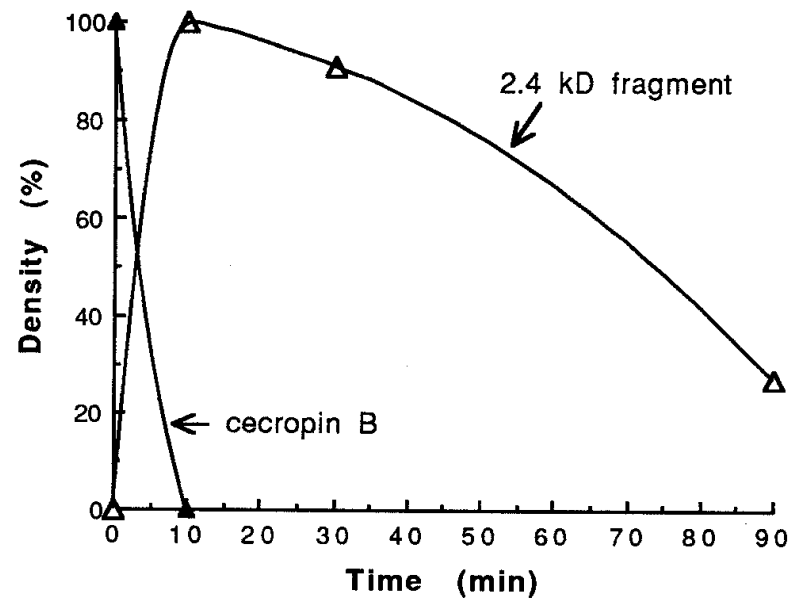

Fig. 3. Time course of cecropin $B$ degradation by potato leaf intercellular fluid (IF). Cecropin B $(2 \mu \mathrm{l}$ of $1 \mu \mathrm{g} / \mu \mathrm{l})$ was incubated with potato IF $(2 \mu \mathrm{l})$ for the lengths of time indicated, subjected to polyacrylamide gel electrophoresis, stained with Coomassie brilliant blue, and scanned with a densitometer as described in Mills et al. (1994).

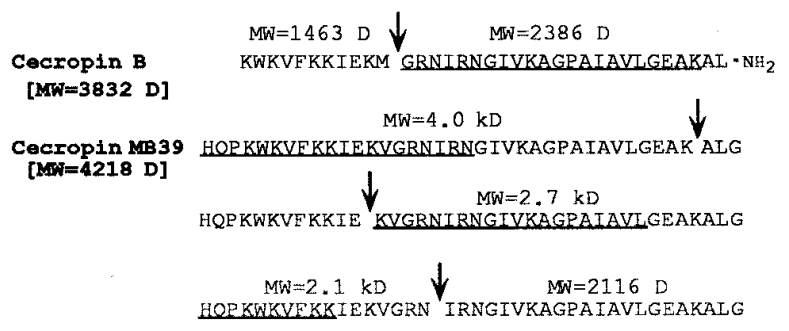

Fig. 4. Degradation fragments produced by treatment of cecropin B and synthetic MB39 with potato leaf intercellular fluid (IF). Underlined amino acid residues were determined by peptide sequencing (G1005A protein sequencer, Hewlett-Packard, Palo Alto, CA) following complete or partial separation of the fragments by tricine-polyacrylamide gel electrophoresis (Mills et al. 1994) and transfer to polyvinylidene fluoride membrane. Fragment molecular weight values were either determined by mass spectrometry (cecropin B degradation fragments and the 2,116-Da MB39 fragment) or estimated from electrophoretic mobility and $\mathrm{N}$-terminal sequence information. Arrows indicate cleavage sites of IF proteases. 
analog in transgenic tobacco confers enhanced resistance to bacterial wilt caused by Pseudomonas solanacearum. Plant Sci. 89: 43-53.

Mills, D., Hammerschlag, F. A., Nordeen, R. O., and Owens, L. D. 1994 Evidence for the breakdown of cecropin B by proteinases in the intercellular fluid of peach leaves. Plant Sci. 104:17-22.

Nordeen, R. O., Sinden, S. L., Jaynes, J. M., and Owens, L. D. 1992. Activity of cecropin SB37 against protoplasts from several plant species and their bacterial pathogens. Plant Sci. 82:101-107.

Norelli, J. L., Aldwinckle, H. S., Destefano-Beltran, L., and Jaynes, J. M. 1994. Transgenic 'Malling 26' apple expressing the attacin E gene has increased resistance to Erwinia amylovora. Euphytica 77:123-128.
Owens, L. D. 1995. Overview of gene availability, identification and regulation. HortScience 30:957-961.

Schaad, N. W. 1988 Initial identification of common genera. Pages 1-15 in: Laboratory Guide for Identification of Plant Pathogenic Bacteria 2nd ed. N. W. Schaad, ed. American Phytopathological Society, St. Paul, MN.

Terras, F. R. G., Eggermont, K., Kovaleva, V., Raikhel, N. V., Osborn, R. W., Kester, A., Rees, S. B., Torrekens, S., Van Leuven, F., Vanderleyden, J., Cammue, B. P. A., and Broekaert, W. F. 1995. Small cysteinerich antifungal proteins from radish: Their role in host defense. Plant Cell 7:573-588. 